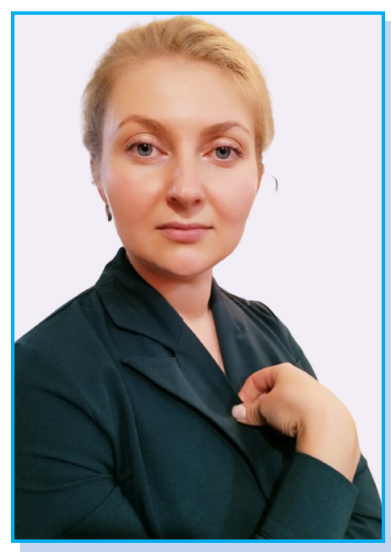

Alina Dzhurylo - PhD (Education), Senior Researcher of the Comparative Education Department, Institute of Pedagogy of the NAES of Ukraine, Kyiv, Ukraine; Assistant Professor of the Department of Foreign Philology and Translation, National Transport University.

Research Interests: comparative and international education; EU policy in the fields of education and training; educational reforms and pedagogical and technological innovations; quality assurance in school education; decentralization of education management.

dzhurylo.ap@gmail.com

https://orcid.org/0000-0002-5129-6724

УДК 373.5.014.25: 477

https://doi.org/10.32405/2411-1317-2021-3-13-23

\title{
GUIDING PRINCIPLES FOR POLICY DEVELOPMENT ON QUALITY ASSURANCE IN SCHOOL EDUCATION: EUROPEAN EXPERIENCE FOR UKRAINIAN SUCCESS
}

In present-day conditions, the quality of education is becoming the most important characteristic that determines the competitiveness of educational institutions and national education systems. The tasks of quality assurance and control are central to the educational reforms of many countries, including Ukraine. The problem of measuring and evaluating learning outcomes is becoming one of the most important in pedagogical theory and practice, as its solution allows to determine the effectiveness and ways to improve the content, methods and organization of learning, management system. Objective, theoretically substantiated measurements and evaluation of learning outcomes can give teachers and heads of educational institutions information about the pedagogical process, educational achievements of each student, identify the impact of various factors on the course of learning and its results. The issue of quality assurance continues to be relevant for Ukraine in the context of the reform of the New Ukrainian School and attempts to create a system of education evaluations, which should focus on four key positions: promoting the quality of primary, basic secondary and complete secondary education; accumulation of objective information about the educational process and learning outcomes of students of general secondary education; support of the educational process in general secondary education institutions (what and how is assessed - that is why attention is paid to the extent of organizing the educational process); supporting teachers, increasing trust in them. The experience of EU countries where similar educational assessment systems have operated successfully can be useful for Ukrainian policy-makers and researchers in the field of education.

Keywords: quality assurance; learning assessments; internal and external evaluation.

\section{Introduction. Problem statement}

Quality policy is the basis, the core of national education policy in many countries. Scholars and politicians note that in the current geopolitical competition, the winner is the one who adheres to the highest priority of science development in domestic politics, who puts education and its quality at the centre of state strategy. Thus, in a broad sense, education quality is the basis of life quality as an individual and society as a whole. For example, countries such as the United States, Germany, Japan, China, and India are 
characterized by the phenomenon of "meritocracy" (a society in which the status of citizens is determined by the level of education). Recently, this trend has significantly intensified in Ukraine.

The category of quality was first analyzed by Aristotle, who defined it as a "species distinction". He was convinced that the higher the level of organization of the system, the more qualities (properties) it has. The quality of education cannot be considered as a static object - it is constantly changing when interacting with other objects, under the influence of external (economic, political, demographic and other) factors [1, p. 2].

For the first time, the issue of education quality was officially raised at the meeting of the ministers of education of the United Europe countries, which took place in 1984. It was then that the ministers, concerned about the state of education, began to study the factors affecting the quality of education. The research resulted in the report "Schools and Quality" [1, p. 8].

In the context of globalization, quality education is positioned by the world community as a prerequisite for successful economic development and social partnership. World Declaration on Education for All (1990) recognized quality education as a precondition for equality, and in the Dakar Framework for Action (2000) proclaimed it the right of everyone.

In the EU countries quality education is recognized as a political priority. High-quality knowledge, skills and abilities of EU citizens are seen as a platform for active citizenship, employment and social harmony. Article 149 of the Treaty on European Union (1992) states that the Community shall support the development of high quality education in the Member States with respect for national interests and traditions [2, p.5].

\section{Literature review}

The issue of quality of general secondary education, assessment of students' academic achievements, monitoring system has been the subject of scientific research for many years both at the national and international levels. Researchers study both quality issues within one country and conduct comparative studies with countries with high educational attainment of students in order to form recommendations for improving their own educational systems. The researchers (A. Dzhurylo [3], O. Glushko [4], O. Lokshyna [5], O. Maksymenko [6], N. Nikolska [7], O. Shparyk [8] of Comparative Education Department in the Institute of Pedagogy of the NAES of Ukraine have conducted a number of studies on this topic, analyzing the best foreign experience and providing recommendations for its implementation in the national educational space. The collective monograph "Quality assurance of general secondary education in the leading countries of Europe and the USA" was published 2014 and devoted to the problem of quality of general secondary education and pedagogical mechanisms of its provision in the leading countries of Europe and the USA. The authors described the approaches to the interpretation of the quality of education in Ukraine and abroad; authentic models of foreign countries used to ensure the quality of secondary education are revealed; the prospects of using foreign experience in Ukraine are outlined [2].

The purpose of an article is to undertake the analysis of guiding principles for policy development on quality assurance in school education in EU countries in the context of the reform of the New Ukrainian School and attempts to create a national system of education evaluations.

\section{Methodology}

By analyzing foreign and Ukrainian sources, regulations and strategies, as well as analyzing and comparing the experience of practical activities of education quality assurance, measuring and evaluating learning outcomes, experience of EU countries in building national quality assessment systems, the common goals and values of school education in Ukraine and in European countries have been identified common features of educational policy and highlights recommendations for effective European practices.

For the validity of the results obtained, the documents of European Commission were analyzed on quality assurance in school education, in particular the guiding principles for policy development on quality assurance in school education.

Recent government initiatives have been analyzed to highlight Ukraine's national education policy on education quality, namely "Strategy for the development of educational assessments in general sec- 
ondary education in Ukraine until 2030” (2019) [9], “Opinions of teachers, school principals, educational experts, students and their parents on the quality of education” (2021) [10] and other.

\section{Main results}

In world educational practice, advanced education systems are based on reliable systems for assessing learning outcomes. Radical changes in control and evaluation activities began to occur in foreign education systems in the middle of the last century. In the scientific and technological revolution of the late XX - early XXI century, there was a diversification of education, due to the expansion of the content of education. The introduction of new teaching methods and technologies related to informatization has become urgent, which has led to the individualization of learning, which is expressed in the variability of programs, the introduction of individual courses and numerous control and training programs.

The intensification of education reform at all levels around the world and the need for appropriate systematic analysis of change based on objective results of pedagogical measurements required the development of new management mechanisms that require reliability and specification of information about the state of educational systems.

In the context of internationalization of education and the creation of a common educational space, there are common approaches to assessing the learning outcomes of schoolchildren, students and professionals.

The fundamental difference between the traditional system of knowledge assessment and pedagogical measurements is that in the first case it is about assessing the quality of academic achievement in the interaction of students with the teacher, and in the second - to obtain quantitative indicators of learning outcomes, usually using pedagogical measures and software and tools.

The advantages of traditional methods are:

- development of students' communication skills;

- simplicity of receptions;

- efficiency of obtaining the result.

Traditional methods are aimed solely at providing qualitative equivalents of the assessed properties of students, and not at their quantitative measurement, so the results of such control cannot be compared.

The disadvantages include:

- incompatibility with modern directions of modernization of education and improvement of its quality management system;

- manifestations of subjectivism on the part of teachers;

- impossibility to determine the true level of achievement due to the latent nature of students' preparedness;

- lack of adequate means of control that correlate with the competence approach in education;

- lack of uniform scales and evaluation criteria;

- weak methodological support for self-assessment and self-correction of educational results.

In contrast to traditional, modern technologies for assessing the quality of educational achievements are based on a "qualimetrics" or quantitative approach, which aims to obtain numerical equivalents that are identified with the estimates of the measured variable. Two latent parameters are considered as the object of research: difficulties of tasks and subject or interdisciplinary preparation of the student. In quantitative measurement of the level of learning outcomes, foreign and domestic scientists have achieved the greatest success, laying in the control and evaluation activities of new areas that have proven their effectiveness at the most important stage "school - External Independent Evaluation" [11].

At the core of the qualimetrics approach to modern testing are the ideas of using mathematical models of design and parameterization of tests according to the methodology of IRT (Item Response Theory), which was developed in the works of foreign scientists [11].

The main assumption of IRT is the presence of a relationship between the observed learning outcomes; latent properties of the persons (students), namely their readiness for the subject at the time of testing; and the characteristics of the test tasks (difficulty levels) that are used.

The latent parameters of the persons being tested are revealed as a result of the interaction of two sets, which determine the results of the test and the results obtained directly from the empirical data of 
the test in the form of the primary score (number of completed tasks). In practice, the task is always to evaluate the value of latent parameters by the number of correctly performed tasks. It is for its solution and choose one or another type of relationship between them (mathematical model), establish the relationship between the empirical test results and the values of these latent variables on the rating scale.

On the basis of this or that mathematical model the test is constructed, on statistically significant sample the necessary quantity of its variants is created and tested, psychometric characteristics are defined and the scale of estimations then the test receives properties of the pedagogical measuring instrument is constructed.

Thus, a comprehensive indicator of students' preparedness in the theory of pedagogical measurements is educational achievements (knowledge and skills) in a particular subject area as an object of test control, and a quantitative measure of the quality of education with a cognitive component is the level of these achievements as a measured parameter, expressed by the number of test scores on the measurement scale.

The true score is considered as a constant (quantitative characteristic of the person undergoing the test at the time of pedagogical measurement), which does not depend on the means of measurement, but changes in the learning process. The role of the scale of pedagogical measurements is played by test tasks with known levels of difficulty (calibrated test tasks), and the objects of assessment are the levels of student achievement; the measurement result is a scale of test scores. Task difficulties and preparedness are reflected on the logit scale. Logit in the theory of pedagogical measurements is a unit of measurement. Thus, like physical measurements, pedagogical signs show all the signs of quantitative measurement [11].

In Ukraine, External Independent Evaluation (EIE) is used as one of the main tools for measuring the quality of education of school graduates. The results of the external independent assessment are determined in two stages - first the test score of the participant of the external evaluation is determined, and on the basis of the test score the rating score of the participant in each subject is determined on a 200-point scale. Composing tests in various subjects, the EIE participant can score a certain number of points for the correct answers to the tasks and get the so-called test score. The test score of the EIE participant is calculated as the arithmetic sum of all points scored for each completed test task in a particular subject. After determining the test score, the evaluation of the EIE participant is determined on a scale from 100 to 200 points - the rating score. This score is used when compiling the rating list of entrants when entering higher education institutions of Ukraine.

To ensure internal quality of education in schools and measure its results, on November 30, 2020, the Ministry of Education and Science of Ukraine approved "Guidelines for the formation of internal quality assurance in general secondary education" to provide guidance to managers and other teachers of educational institutions in the organization work on defining the policy of quality assurance of educational activities, formation of the internal system of quality assurance of education, development of tools for its analysis and evaluation [12].

The Guidelines state that the strategy (policy) for ensuring the quality of education should be focused on ensuring:

- compliance of students' learning outcomes with state educational standards;

- partnerships in learning and professional interaction;

- non-discrimination, prevention and counteraction to bullying;

- academic integrity during training, teaching and conducting scientific (creative) activities;

- transparency and information openness of the educational institution;

- conditions for continuous professional growth of teachers;

- fair and objective assessment of students' learning outcomes, as well as the professional activities of teachers;

- conditions for the implementation of individual educational trajectories of students (if necessary);

- academic freedom of teachers.

In April 2018 by European Commission were published Guiding principles for policy development on quality assurance in school education "Quality assurance for school development” as output of the 
ET2020 Working Group Schools 2016-18. The research-based recommendations pointed towards a need for greater coherence and synergy in quality assurance approaches - in particular, the effective interplay between internal and external mechanisms - in order to ensure that they best serve school development and innovation [13].

According to the research quality assurance approaches include mechanisms that are external and internal to schools. External mechanisms include national or regional school evaluations and/or largescale student assessments. Internal mechanisms include school self-evaluation, staff appraisal and classroom-based student assessments. These mechanisms have different but complementary purposes. They are parts of a coherent, integrated system, with the different mechanisms supporting and reinforcing each other. This kind of productive synergy ensures a clear focus on school development, providing data on aspects such as school climate and the well-being of all members of the school community, effective teaching and learning, and the impact of innovations.

The report set out eight principles developed by the ET2020 Working Group on Schools to guide policy-making related to quality assurance and, in particular, to ensure a productive synergy of external and internal quality assurance mechanisms.

COHERENCE

PROFESSIONAL LEARNING COMMUNITIES

TRUST AND SHARED ACCOUNTABILITY

SUPPORT INNOVATION

SHARED UNDERSTANDING AND DIALOGUE

NETWORKS

BUILDING CAPACITY FOR DATA

DIFFERENT DATA FOR BALANCED VIEW
- achieve balance and coherence

- meet the demands and expectations of stakeholders

- support professional learning communities

- make best use of quality assurance data for school

- trust and respect both internal and external actors of educational processes

- innovate and develop school space with taking considered risks

- attention to data on the impact of innovations, including potential unintended outcomes

- support the development of a common language and shared understanding among internal and external actors

- support collective engagement; build social and intellectual capital; spark new synergies across school systems

- generate, interpret and use data

- gather quantitative and qualitative data for a balanced understanding of school development and learner progress

Figure 1. The eight guiding principles for policy development on quality assurance in school education [13, p 3]

National education systems of European countries are different, but countries share several common policy challenges and opportunities in their approach to quality assurance. These include how to:

- set goals and measure progress for education systems and student learning;

- design quality assurance for education systems that are increasingly diverse,

- decentralised and multi-level;

- support and encourage dialogue and cultures of trust between and among education stakeholders;

- ensure transparency of quality assurance data while also avoiding the pressure of high stakes approaches;

- prioritise human and financial resources. 
Many countries are engaged in continuing or recent reforms, ranging from a general introduction of quality assurance mechanisms, the introduction of specific measures, the adoption of national frameworks, or the formal incorporation of PISA results.

Most EU countries have created frameworks that integrate some combination of internal and external quality assurance mechanisms:

- Inspectorates;

- National student assessments;

- School self-evaluation;

- Teacher appraisal.

The report underlines that only internal or only external quality assurance mechanism cannot provide all the information needed for school accountability and development. Taken together, the different mechanisms can provide important and complementary insights on school, teacher and student performance and support evidence-based decision-making.

By the members of the ET2020 Working Group was developed a model of the relation between different elements of the system in terms of accountability, reporting and priority-setting as a representation of typical relationships between system actors. This may provide a useful reference for reviewing the roles of stakeholders, decision-making processes, and the flow of data. Whilst there are variations, priority-setting is often done externally and imposed on the schools and the school is accountable in return [13].

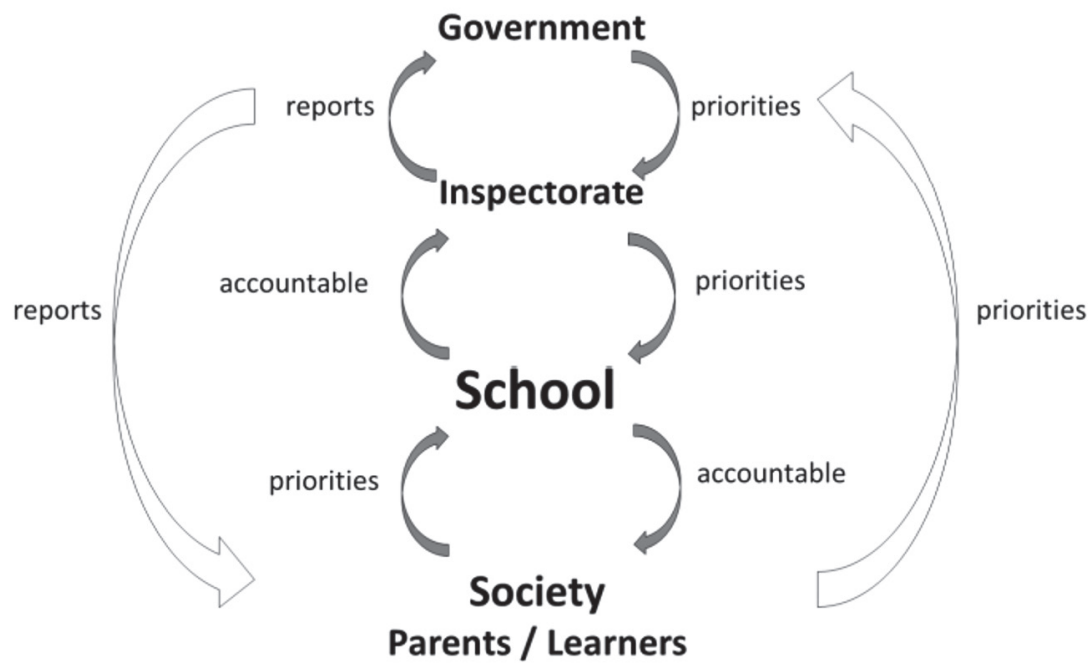

Figure 2. Graphical representation of the relation between different elements of the system in terms of accountability, reporting and priority-setting [13, p. 8]

In EU schools, external institutions and actors work together to define strategies and alternatives for school improvement. For example, in Croatia, school self-evaluation was initiated 15 years ago, but their opinion is that it was not really effective until external evaluation was introduced. For more than a decade, Slovenia has been gradually developing its quality assurance approach: setting up a national framework to support fairness, quality and efficiency of education systems. The purpose is to define a common concept of quality assurance at the level of educational institutions (early years, primary and secondary schools) and, indirectly, system-level evaluation. The trans-sectoral approach and development of school leader capacity are seen as strengths. In Iceland, external evaluators base their analysis and judgments of school performance on data gathered as part of the Quality Indicators framework; Internal evaluation results are intended for use by the school to highlight and improve various aspects 
of its own performance and practices. In Italy, the National System for Evaluation of schools, that was first implemented only in 2014-15, ensures all relevant actors and stakeholders are involved. It follows a three-year cycle: Each school was initially provided with a wide set of data on its resources, processes and outcomes, and was then asked to produce a self-evaluation report identifying strengths and weaknesses, based on a standardised template from the National Agency for School Evaluation. In Poland external evaluation is carried out by regional inspectorates and comprises two aspects: 1) evaluating school quality, and 2) checking compliance with legislation. External school evaluations have an advisory character and schools formulate their own action plans based on the findings [13, p. 11-13].

It is worth noting the government's initiatives to survey the views of all stakeholders on the quality of education. For instance, on March 2, 2021, the results of the study "Opinions of teachers, school principals, educational experts, students and their parents on the quality of education" were presented to the public. The study was conducted by the research agency "Vox Populi Agency" commissioned by the State Education Quality Service of Ukraine in October-November 2020 [10].

A representative sample of target schools was developed for the study. The sample covered 13 oblasts, 60 schools, which reproduce the structures by regional and by type of settlement, which ensured the representativeness of the obtained results. The survey was conducted by online interview. A total of 59 principals, 1,560 teachers, 1,631 parents, 899 students and 752 experts were interviewed. Among the most important criteria, which, according to experts, school principals, teachers, students and their parents, indicate that the school provides quality education, are:

- mastering key competencies (91\% of experts, $81 \%$ of school principals and $70 \%$ of students consider it important),

- mastering cross-cutting skills (82\% of experts and 69.5\% of directors),

- comprehensive development of students (67\% of experts and 78\% of school principals).

- In their answers, parents first name the following criteria:

- curiosity in learning (71\%);

- all-round development (54\%);

- competencies (50\%).

At the same time, the survey revealed that the main criteria for students are the following:

- competencies (70\%);

- curiosity inlearning (66\%);

- high results of External Independent Evaluation (49\%);

- all-round development (47\%).

All categories of respondents mentioned the acquisition of key competencies as one of the main criteria for the quality of education.

The main priority in the ranking for teachers and students is to provide the school with all-round student development. Equally important for children and parents, along with competencies, is the curiosity in learning (66\% and $71 \%$ respectively).

Among the factors that most affect the quality of education, the first in the ranking for experts, principals, teachers and parents are:

- cooperation between all actors of educational process;

- safe learning environments (no bullying / harassment or discrimination based on gender, religion, family income, place of residence, etc.);

- qualification of pedagogical workers and comfortable psychological environments.

School principals and teachers have chosen as the number one priority such factors as cooperation between the participants of the educational process and a comfortable psychological environments, and parents - a comfortable psychological environment and excellence in teaching.

The largest percentage of students (78\%) noted that friendly relations between students and teachers, mutual respect, lack of bullying / harassment are the factors that make the school good and quality. Every third student considers this criterion the most important. The other most important criteria for students are interesting lessons (54\%) and excellence in teaching (47\%). 
Significant differences between students in rural and urban schools are observed in terms of interesting lessons - this factor proved to be more important for children in urban schools ( $57 \%$ vs. $48 \%$ in rural areas).

The factor of excellence in teaching for children from urban schools turned out to be more important (52\% vs. $41 \%$ in rural areas). At the same time, the factor of students' sense of security in school is more important for students of rural schools (it was chosen by $42 \%$ of students in rural schools and 33\% in urban schools).

Experts, principals, teachers and parents are unanimous in their opinion that teachers, students and their parents are responsible for the quality of students' education. At the same time, the prevailing opinion among students is that the main responsibility lies with the students and teachers, and $58 \%$ of students consider themselves the most responsible [10].

There are still some other government initiatives, particularly "A quality school is an environment in which a child is happy" - information campaign on the quality assurance system of education in Ukrainian schools conducted by the Ministry of Education and Science of Ukraine together with the State Education Quality Service [14].

The aim of the campaign is to inform parents, students, school principals, teachers and the community about what a quality school should be like and how a new education quality assurance system and each participant in the educational process can help the institution become better.

The campaign was created within the initiative "Education Quality Assurance System”, which is implemented within the project "Support to Government Reforms in Ukraine" and launched in the second quarter of 2021.

\section{Conclusion, discussion and suggestions}

Unfortunately in Ukraine there is no evaluation system that deeply monitors all levels of the education system, from start to finish, and accumulates a single database. At this moment in time only separate fragments of the system of internal or external educational assessments really function (irregular monitoring studies in some classes, State Final Attestation in 4th and 9th grades, External Independent Evaluation only after 11th grade).

The information that is obtained as a result of these fragments of the system of external educational evaluation is undoubtedly significant, but it is not sufficient to improve the quality of education and educational activities, to provide an objective vision of the state of national education, understanding where stages, for what reasons problems arise, when and how it is possible to influence the situation in order to correct it, etc.

Sad to say, but Ukraine has not still established a national system for monitoring the quality of education. This makes it impossible to form an effective educational policy, leads to inefficient use of budget and private funds, devalues the essence and content of educational activities, leads to the emergence of corruption schemes and, ultimately, significantly affects the national security of the state. Existing regulations on monitoring and evaluating the quality of education cannot ensure the establishment of such a system. They are focused on obtaining formal indicators, conducting unsystematic situational control procedures, the development of centralization processes in the management of the educational system. Ukrainian researchers and policy-makers have still been working on developing a concept and model of a national system for monitoring the quality of education. Existing program and regulatory documents are limited to the proclamation of declarations such as "quality improvement" instead of defining its specific indicators that need to be achieved and whose achievements can be measured. This does not make it possible to move from quality assurance slogans to concrete actions to ensure quality.

Although in comparison with the last decade there have been some changes in the formation of a system for monitoring the quality of school education. Evidence of this is the following examples: coverage in recent years of external independent evaluation of the system of vocational (technical) education; conducting in 2018 the first cycle of the national monitoring study of the quality of primary education "The state of formation of reading and mathematical competencies of primary school graduates of general secondary education”, Ukraine’s participation in TIMSS-2011 and PISA-2018. 
Another step of Ukraine on the way to forming a system for monitoring the quality of education was the adoption at the end of 2019 of the Ministry of Education and Science of Ukraine "Strategy for the development of educational assessments in general secondary education in Ukraine until 2030" [9].

This document aims to propose a system of external educational evaluation for its implementation in the context of the reform of general secondary education, defined by the Concept of the "New Ukrainian School", taking into account the problems outlined above. The proposed system of external educational evaluation is focused on four key positions:

- promoting the quality of primary, basic secondary and specialized secondary education;

- accumulation of objective information about the educational process and learning outcomes of students of complete general secondary education;

- support of the educational process in the general secondary education institution (depending on what and how it is assessed - that is why attention is paid to the extent of organizing the educational process);

- maintaining the pedagogical skills of teachers, providing them with objective information on the quality of educational activities, increasing trust in them.

However, as the experience of EU countries shows, the system of monitoring the quality of educational outcomes should include effective interplay between internal and external evaluation mechanisms. New quality assurance approaches should start from the strengths of schools and school education systems and be developed and monitored from there. In considering new approaches, it is useful to make some tactical planning, particularly in being prepared for the reaction of stakeholders: a stronger, two-way dialogue between stakeholders should be envisaged. School self-evaluation should be strengthened, including capacity-building for school leaders and teachers; learning from other sectors that have regularly engaged in internal monitoring; and developing tools where appropriate. The role of external evaluation agents should be to facilitate improvement for example through follow-up with schools in identified needs and through disseminating good practices. And the last but not the least our education policy-makers should take a forward-looking perspective: not dwelling on past needs but acting towards a vision of the future.

\section{Використані джерела}

[1] Л. Швидун, «Моніторинг якості освіти» Комунальний заклад вищої освіти «Дніпровська академія неперервної освіти» Дніпропетровської обласної ради, 123 с., 2020.

[2] Л. Л. Волинець та ін., «Забезпечення якості загальної середньої освіти у провідних країнах Європи та США», монографія: А. П. Джурило, Г. С. Єгоров, Н. М. Лавриченко, О.І. Локшина, Б. Ф. Мельниченко, О. С. Оржеховська, О. О. Першукова, Н. В. Шеверун, О. М. Шпарик, за заг. ред. Локшиної О. І., Київ, Україна: Інститут педагогіки НАПН України, 374 с, 2014.

[3] А. П. Джурило, «Перспективність досвіду Великої Британії із забезпечення якості загальної середньої освіти в Україні», Проблеми сучасної педагогічної освіти, № 46(6), с. 64-71, 2014.

[4] О. 3. Глушко, «Європейський вектор освітніх реформ в Україні», Український педагогічний журнал, № 4. с. 5-11, 2017.

[5] О. І. Локшина, «Європейська і світова інтеграція в галузі освіти - шлях до підвищення якості освіти «, в «Національна доповідь про стан і перспективи розвитку освіти в Україні», за заг. ред. В. Г. Кременя, Київ : Педагогічна думка, 2016, с. 164-173.

[6] О. О. Максименко, «Новітні технології оцінювання у напрямі професійно-орієнтованого навчання іноземних мов: погляд вчених зарубіжжя», Наукові записки (серія педагогічні та історичні науки), Випуск СXX(120), с. 112-120, 2014.

[7] Н. В. Нікольська «Тенденція підвищення якості шкільної освіти у США крізь призму законодавства», Звітна наукова конференції Інституту педагогіки НАПН України «Анотовані результати науково-дослідницької роботи інституту педагогіки за 2019», Київ, 2019, с. 74-75.

[8] О. М. Шпарик, «Моніторингові дослідження китайських науковців у галузі забезпечення якості загальної середньої освіти у країнах Європи», Нові технології навчання, № 77, с. 32-36, 2013. 
[9] Міністерство освіти і науки України (2019). Стратегія розвитку освітніх оцінювань у сфері загальної середньої освіти в Україні до 2030 року. [Електронний ресурс]. Доступно: https://testportal.gov.ua//wpcontent/uploads/2019/07/190523_Strategiya-osvitnih-otsinyuvan_UTSOYAO.pdf

[10] Державна служба якості освіти України (2021). Що думають про якість роботи школи і якість освіти директори шкіл, учні, їхні батьки та освітні експерти. [Електронний ресурс]. Доступно: https://nus. org.ua/wp-content/uploads/2021/03/SHHo_dumayut_yakist_osvity_brief_education_quality_2020.pdf

[11] Frederic M. Lord, «Application of Item Response Theory to Practical Testing Problems. Hillsdale» NJ: Lawrence Erlbaum Associates, 266 p., 1980.

[12] Міністерство освіти і науки України (30.11.2020 № 1480). Методичні рекомендації з питань формування внутрішньої системи забезпечення якості освіти у закладах загальної середньої освіти. [Електронний ресурс]. Доступно: https://mon.gov.ua/storage/app/media/rizne/2020/11/30/nakaz\%201480.pdf

[13] European Commission (April 2018). Quality assurance for school development. [Електронний ресурс]. Доступно: https://www.schooleducationgateway.eu/downloads/Governance/2018-wgs2-quality-assuranceschool_en.pdf

[14] Державна служба якості освіти України «Якісна школа - це середовище, у якому дитина щаслива». [Електронний ресурс]. Доступно: https://qualityeducation.org.ua/?fbclid=IwAR2s0iwC4n3Y4Horn0NNt R56H_LQ_BfNHSjRDL8dkx-uG583MUHQuRd1hUc\#myths

\section{References}

[1] L. Shvydun, «Monitoring the quality of education», Municipal institution of higher education «Dnipro Academy of Continuing Education» of Dnipropetrovsk Regional Council, 123 p., 2020.

[2] L. L. Volynez and other, «Ensuring the quality of general secondary education in the leading countries of Europe and the United States», monograph: A.P. Dzhurylo, G.S. Egorov, N.M. Lavrychenko, O.I. Lokshyna, B.F. Melnychenko, O.S. Orzhekhovska, O.O. Pershukova, N.V. Sheverun, O.M. Shparyk, for the general ed. by O.I. Lokshyna, Kyiv, Ukraine: Institute of Pedagogy of the National Academy of Pedagogical Sciences of Ukraine, 374 p., 2014.

[3] A. P. Dzhurylo, «Prospects for the experience of the United Kingdom in ensuring the quality of general secondary education in Ukraine», Problems of modern pedagogical education, № 46(6), pp. 64-71, 2014.

[4] O. Z. Glushko, «European vector of educational reforms in Ukraine», Ukrainian pedagogical journal, № 4. pp. 5-11, 2017.

[5] O. I. Lokshyna, «European and global integration in education - a way to improve the quality of education», in «National report on the state and prospects of education in Ukraine», for general ed. V. G. Kremenya, Kyiv: Pedagogichna Dumka, 2016, pp. 164-173.

[6] O. O. Maksymenko, «Latest assessment technologies in the direction of professionally-oriented learning of foreign languages: the view of foreign scholars», Scientific notes (series of pedagogical and historical sciences), Issue CXX(120), pp. 112-120, 2014.

[7] N. V. Nikolska «Trend of improving the quality of school education in the United States through the prism of legislation», Reporting scientific conference of the Institute of Pedagogy of the National Academy of Pedagogical Sciences of Ukraine "Annotated results of research work of the Institute of Pedagogy in 2019», Kyiv, 2019, pp. 74-75.

[8] O. M. Shparyk, «Monitoring research of Chinese scientists in the field of quality assurance of general secondary education in European countries», New learning technologies, № 77, pp. 32-36, 2013.

[9] Ministry of Education and Science of Ukraine (2019). Strategy for the development of educational assessments in the field of general secondary education in Ukraine until 2030. [Online]. Available: https://testportal.gov. ua//wp-content/uploads/2019/07/190523_Strategiya-osvitnih-otsinyuvan_UTSOYAO.pdf

[10] State Education Quality Service of Ukraine (2021). What do school principals, students, their parents and educational experts think about the quality of school work and the quality of education?. [Online]. Available: https://nus.org. ua/wp-content/uploads/2021/03/SHHo_dumayut_yakist_osvity_brief_education_quality_2020.pdf

[11] Frederic M. Lord, «Application of Item Response Theory to Practical Testing Problems. Hillsdale», NJ: Lawrence Erlbaum Associates, 266 p., 1980.

[12] Ministry of Education and Science of Ukraine (30.11.2020 № 1480). Guidelines on the formation of the internal system of quality assurance in institutions of secondary education. [Online]. Available: https://mon. gov.ua/storage/app/media/rizne/2020/11/30/nakaz\%201480.pdf 
[13] European Commission (April 2018). Quality assurance for school development. [Online]. Available: https:// www.schooleducationgateway.eu/downloads/Governance/2018-wgs2-quality-assurance-school_en.pdf

[14] State Education Quality Service of Ukraine «Quality school is an environment in which a child is happy». [Online]. Available: https://qualityeducation.org.ua/?fbclid=IwAR2s0iwC4n3Y4Horn0NNtR56H_LQ BfNHSjRDL8dkx-uG583MUHQuRd1hUc\#myths

Аліна Джурило, кандидат педагогічних наук, старший науковий співробітник відділу порівняльної педагогіки Інституту педагогіки НАПН України, доцент кафедри іноземної філології та перекладу Національного транспортного університету, м. Київ, Україна.

\section{КЕРІВНІ ПРИНЦИПИ РОЗРОБЛЕННЯ ПОЛІТИКИ ЗАБЕЗПЕЧЕННЯ ЯКОСТІ ШКІЛЬНОЇ ОСВІТИ: ЄВРОПЕЙСЬКИЙ ДОСВІД ДЛЯ УСПІХУ УКРАЇНИ}

У сучасних умовах якість освіти стає найважливішою характеристикою, що визначає конкурентоспроможність освітніх установ і національних систем освіти. Завдання забезпечення та контролю якості є основними для освітніх реформ у багатьох країнах, включаючи Україну. Проблема вимірювання та оцінювання результатів навчання стає однією з найважливіших у педагогічній теорії і практиці, так як її вирішення дає змогу визначити ефективність і шляхи поліпшення змісту, методів і організації навчання, системи управління. Об’єктивні, теоретично обгрунтовані вимірювання та оцінка результатів навчання можуть дати вчителям і керівникам освітніх установ інформацію про педагогічний процес, навчальні досягнення кожного учня, виявити вплив різних чинників на процес навчання і його результати. Проблема забезпечення якості залишається актуальною для України в контексті реформи Нової української школи та державної ініціативи створення системи оцінювання освіти, яка має бути зосереджена на чотирьох ключових позиціях: сприяння підвищенню якості початкової, базової середньої та профільної середньої освіти; накопичення об'єктивної інформації про освітній процес і результати навчання здобувачів повної загальної середньої освіти; супровід освітнього процесу в загальноосвітніх закладах середньої освіти (залежно від того, що і як оцінюється - тому й тією мірою приділяється увага під час організації освітнього процесу); підтримування педагогічної майстерності вчителів, надання їм об’єктивної інформації щодо якості освітньої діяльності, підвищення довіри до них. Досвід країн ЄС, де аналогічні системи оцінювання освітніх досягнень успішно працюють, може бути корисний українським політикам та дослідникам у галузі освіти.

Ключові слова: гарантія якості; оцінювання навчальних досягнень; внутрішній та зовнішній моніторинг. 